Journal of Economics and Behavioral Studies

Vol. 4, No. 1, pp. 47-54, Jan 2012 (ISSN: 2220-6140)

\title{
Volatility Linkages between Equity Markets of Pakistan, India, Singapore and Hong Kong: A GARCH BEKK Approach
}

\author{
${ }^{*}$ Muhammad Junaid Iqbal ${ }^{1}$, Sadia Rafique ${ }^{1}$, Afsheen Abrar ${ }^{1}$, Nagina Jamil ${ }^{1}$, Abid Ali Shah ${ }^{2}$, AhsanulHaqSatti ${ }^{2}$ \\ ${ }^{1}$ ShaheedZulfikar Ali Bhutto Institute of Science and Technology, Islamabad, Pakistan \\ 1 International Islamic University, Islamabad, Pakistan \\ *strive4me@gmail.com
}

\begin{abstract}
The purpose of current study is to explore the volatility linkages between four Asian equity markets, which arePakistan (Karachi Stock Exchange), India (Bombay Stock Exchange), Hong Kong (Hang Sang Index) and Singapore (Strait Time Index). We estimate Multivariate GARCH BEKK model using weekly returns from January 2000 to August 2011.Direct evidences of linkages are found among all markets with respect to conditional mean returns and volatility.Own volatility spillover is found greater than cross volatility spillover in all emerging and developed economies.The insinuation of this study is that overseas investors may take advantage from the decrease of uncertainty by accumulating the stocks in the emerging markets to their investment portfolio.
\end{abstract}

Keywords: Volatility linkages, Multivariate GARCH BEKK, Equity Markets

\section{Introduction}

As the world economy globalizes, the economic changes in one region start making significant effects on other regions. There is a vital need to explore the dynamics of those effects as to how they may relate to one another in future and be able to predict the effect of trends developing in one region to the other regions and local economies. Globalizations of the markets have gone through many structural variations, in an attempt to attract foreign investments and diversify its range of portfolios, the markets have become liberalized and it enables the access to remote cross-border trading. They have carried regulatory changes to increase its share of foreign trade. Sabri (2006) have adopted 1641 regulatory changes from 70 countries that favor foreign investments during the 90 's up to 2002. More specifically the equity market integration can be referred by how any change in the prices of an asset in one market attracts the attention of the investor in other markets, which also reflects the price interdependency among different stock markets. Kenen (1976) contended equity market integration in terms of price interdependencies among the stock markets. In this study, he described the price changes in one-market effects the prices of that asset in other markets. However, this equity market integration does not go without overall economic integration of the countries. The economic integration plays an essential role in the sub-markets integration. As the trade among the countries upsurges, the movement of capital flow causes the firms to list in the equity markets of all the countries that allows the transfer of the stocks among the equity markets.

Another aspect of internationalization of the equity markets is the use of internet in the trading. Internet trading has increased the speed of the trading decision, market efficiency and foreign share in the equity markets. Another phenomenon that occurs is the cross listing with big multinational corporations listed in more than one stock exchanges and the use of GDR's (Global Depository Receipts) have enabled firms to be listed and traded on more than one stock market (Sabri, 2006). The deregulation of the equity markets with the progressions in the communication and information technology along with the use of the policy of adopting the floating exchange rates has lowered the intra markets transaction costs. There is rising evidence in the literature which sustenance the hypothesis that there are volatility linkages between the equity markets in the developed world. These markets are integrated with one another and volatility in one market develops changes in the other markets related to it. These volatility linkages are relevant in international portfolio trading and hedging strategies and provide information about the transmission of news across markets. Another fact proved by researches that the more developed and stronger markets such as the US, Japan and other developed equity markets have spillover effects on the less developed markets that are integrated with them. 
Apart from the developed equity, markets are influencing the other developed equity markets; there is also a need to examine the effect of regional equity markets on one another as to how they may relate to each other and which market has spillover effect on other regional markets. In this study, such relationship is examined among Karachi Stock Exchange (Pakistan), Mumbai Stock Exchange (India), Hang Seng indices (Hong Kong) and the Singapore Exchange (Singapore). Sariannidis et al (2006) argued that Honk Kong and Singapore are developed economies and India is rapid developed economy in South Asian region while Pakistan is emerging economy in that region. Volatility linkages among these developed countries have been found by many researchers in previous studies. In this scenario, current study is important to examine the volatility linkages between the equity markets of developed economies such as; India, Singapore and Hong Kong with emerging economy like Pakistan, which will pave the way for overseas investors to take advantage from the decrease of uncertainty by accumulating the stocks in the emerging market to their investment portfolio. According to our finest knowledge, this study has been done first time in Pakistan, which examines the volatility linkages among these four markets by using BEKK GARCH (Baba, Engle, Kraft and Kroner) model proposed, by Engle and Kroner (1995). Remaining portion of this study includes literature review, methodology, analysis and conclusion.

\section{Literature Review}

During the equity market bangs of 1987, all the international stock markets went down at the same time. However, the economic dimensions and conditions in each country were different which gave us the evidence about the volatility between the major global stock markets. Study of King and Wadhwani (1989) provided us the evidence about that transmission of volatility during the crash in which the failure of the market mechanism in one market effected the investor's perception in the other markets and other parts of the world. The initial studies present in the literature has engrossed on finding the linkages between the national stock markets, these studies intended at finding the co-movements among the stock markets through correlations. After that, those studies have shifted focus in finding the prognostic power of the returns by finding the correlations among each equity market's returns and the lagged values of the other foreign equity markets return. Such type of studies used unvaried regressions, the VAR models and co-integration techniques in finding the dynamic interactions and linkages among different equity markets.

The more current researches however, have moved their attention in finding the phenomenon of volatility linkages and its transmission among the equity markets. These current researches have used the GARCH (Generalized Auto Regressive Conditional Heteroskedasticity) proposed by (Engle, 1982) and (Bollerslev, 1986) methodology and its diverse extensions in estimating the effect of volatility spillovers and how volatility in one market effects other markets by inducing volatility in that market. Such studies also examine the effect of previous and current shocks on the volatility of the markets. Worthington and Higgs (2004) examined the volatility among the art markets. The assessed coefficients from the conditional mean return equations specify that all art markets show significant own mean return spillovers. They also found strong own and cross-persistent volatility. Worthington et al (2001) found price linkages in Asian emerging markets. Bekaert and Harvey (1997) provided a method that permits the relative significance of world and local information with respect to expected return and conditional variance procedure. They also concluded that volatility linkages are different in emerging markets. Ramchand and Susmel (1998) contented that during high volatility period in the US markets the foreign markets are highly correlated with them. It is verified by examining time varying and correlation among the US and the foreign markets and due to changing variances the covariance among them changes over the time. As far as the US investors are concerned, the diversification decision depends on the state of time varying variances and the covariance between the US markets and the foreign markets. Anoruo et al (2003) has conducted a study on the dynamic relationship among the six newly industrialized economies and the impact of US and Japan on these economies and finds that these markets are co integrated while Singapore has the most significant impact.

Sariannidiset et al (2006) studied the volatility linkages between the stock markets of Hong Kong, India and Singapore by using multivariate diagonal GARCH BEKK model. They concluded evidences of highly integrated and responsive markets in returns and volatility but they did not explore cross-country associations. Stock returns are expected in the markets of US, UK and Japan. This predictability carries over to the conditional volatility of stock returns (Dimitrios, 2000). Hamao et al (1990) studied the price interdependencies between 
the three major markets Tokyo, New York and London using the ARCH model. They gave evidence of price volatility spillovers among New York to Tokyo; London to Tokyo and New York to London. Hameed and Ashraf (2006) employed ARCH and GARCH $(1,1)$ methodology to test the weak form of efficiency in the Karachi Stock Market and they concluded that returns exhibit persistence and volatility. Choudhry (2004) found the linkages among the foe and friendly countries specified the bidirectional mean and volatility spillover among countries that are not on friendly terms. Their results also provide plenty of indication that mean and volatility spillover take place among friendly countries on large distances. There are strong evidences about cross-country volatility spillover effects during the banking crises in the Scandinavian countries (Hyytinen, 1999). This is a proven fact that the most developed equity markets of American and European countries have spillover effect on the Asian markets. Kumar et al (2008) contended that most of the Asian stock markets are influenced by lag returns of European and US stock markets.

They found that spillover effect among equity market takes place from US market to Japan and Korea market to Singapore, Taiwan market to Hong-Kong to European market to US and so on. However, some studies found that the intra continental volatility linkages are much stronger than the inter-continental volatility linkages (Dekker and Young, 2001). Hashmi and Liu (2001) focused on the 1997's Asian financial crisis and analyzed the linkages among the New York, Japan's and the East Asian countries. They concluded that New York stock market has strong effect on the region while Tokyo Stock Market has absolutely no linkages, while within the region Singapore emerges as a strong leader after the crisis and the inter country linkages further increases after the crisis. Adwin (2005) also focused on the financial crisis in his study on the ASEAN region and concluded that all the countries in the region are highly correlated and they move along very closely. Anoruo et al (2003) has also studied volatility spillover effect during the Asian Financial Crisis. The study shows high co-integration among the Newly Industrialized Countries (NICs, which include Singapore, India, Korea, Hong Kong, Malaysia and Thailand) and with US and Japan and provides evidence about the strong integrated equity markets of these countries and the world major stock markets of USA and Japan.

Isakov and Pérignon (2000) used GARCH (BEKK) model, found the volatility, and return linkages between the Swiss stock market and major international markets that includes United States, Japan, United Kingdom, Germany and France's equity markets. This study also found positive correlations between the Swiss and other stock markets, which is evidence about the co-movement of these markets internationally. Another study conducted by Beirne et al. (2009) aimed at analyzing the global, regional spillover effects among Emerging Market Economies (EME's), and Mature developed markets. They found that spillover effect is present in majority of EMEs. Syllignakis and Kouretas (2008) contended about the European Union agreement of the eastern EU countries that replaced as an alleviating factor for the smoothing of volatility of these emerging capital markets. Saleem (2009) has found the volatility linkages among Russian stock market and world markets by employing multivariate GARCH BEKK model. He found direct linkage among Russian stock market with respect to volatility and returns, while the faintness of the linkage proposes that the Russian equity market was only incompletely combined into the world market.

\section{Methodology}

Data used in current study is drawn from value-weighted indices of the Pakistan (KSE), India (BSESN), Singapore (STI) and Hong Kong (Hang Seng index) from the period of January 2000 to August 2011. Weekly data is specified for the purpose of analysis. There are different views about daily and weekly types of data. Contended that daily data is better for estimation as compared to weekly and monthly returns and argued, "Longer horizon returns can obscure transient responses to innovations which may last for few days only". On the other hand Roca (1999), Ramchand and Susmel (1998), Tay and Zhu (2000) have used weekly data instead of daily data for estimation of Multivariate GARCH model. Roca (1999) argued against daily data due to "noise" which is exaggerated by the day of the week effect while monthly data exaggerated by the month of the year effect. All indices are converted into US dollar for removing the currency effect. Data is taken from web site of Yahoo Finance. Pair wise model is assessed by using Multivariate GARCH BEKK analysis. These pairs are Pakistan - India, Pakistan - Hong Kong, Pakistan - Singapore, India - Hong Kong, India - Singapore and Hong Kong - Singapore. Weekly returns of these all indices are estimated by following formula,

Returns $_{\mathrm{t}}=\log \left(\mathrm{P}_{\mathrm{t}} / \mathrm{P}_{\mathrm{t}-1}\right) \times 100$ 
Model Description: Engle (1982) projected ARCH (Auto Regressive Conditional Heteroskedasiticity) model and after that, Bollerslev (1986) proposed GARCH (Generalized Auto Regressive Conditional Heteroskedasiticity) for volatility modeling of equity market returns. For examining volatility associations among different countries, most studies have used Multivariate GARCH BEKK model that was proposed by Engle and Kroner (1995). Vital features of this multivariate GARCH BEKK model, which differentiate it from previous models, are that it confirms positive definiteness. This model delivers cross-market effects in variance equation. Empirically, following model is employed to inspect the joint procedures linking to the equity market returns.

$\mathrm{Y}_{\mathrm{t}}=\gamma_{\mathrm{o}}+\gamma \mathrm{Y}_{\mathrm{t}-1}+\mathrm{e}_{\mathrm{t}} \quad \mathrm{e}_{\mathrm{t}} / \Omega_{\mathrm{t}-1} \sim N(\mathrm{O}, \mathrm{Ht})$

Where;

$\mathrm{Y}_{\mathrm{t}}=n \times 1$ vector of daily or weekly stock market returns at time $\mathrm{t}$.

$\gamma=n \times n$ matrix parameters linked with lagged returns. In this $4^{*} 4$ matrix off-diagonal measure the cross country effect, while diagonal capture the impact of own previous returns.

$\mathrm{e}_{\mathrm{t}-1}=n \mathrm{x} 1$ vector of random shocks, represents the innovation for each market at time " $\mathrm{t}$ ".

$\mathrm{H}_{\mathrm{t}}=n \times n$ conditional variance-covariance matrix.

$\Omega_{\mathrm{t}-1}=$ Information available in market at time $\mathrm{t}-1$.

$\gamma_{\mathrm{o}}=$ Represents constant term.

From above mentioned model, $\mathrm{H}_{\mathrm{t}}$ represents conditional variance-covariance matrix. Engle and Kroner (1995) can further specify it as follow,

$H_{t}=C_{o}^{\prime} C_{o}+A_{11}^{\prime}$ et - $^{\prime} e_{t-1} A_{11}+G_{11}^{\prime} H_{t-1} G_{11}$

Individual elements for $\mathrm{A}, \mathrm{G}$ and $\mathrm{C}$ matrix are given as:

$A=\left[\begin{array}{ll}a 11 & a 12 \\ a 21 & a 22\end{array}\right] \quad G=\left[\begin{array}{ll}g 11 & g 12 \\ g 21 & g 22\end{array}\right] \quad C=\left[\begin{array}{cc}c 11 & c 12 \\ 0 & c 22\end{array}\right]$

Where;

$\mathrm{H}_{\mathrm{t}}=$ Conditional variance-covariance matrix.

$\mathrm{C}=n \times n$ constant matrix for lower triangular.

$\mathrm{A} \& \mathrm{G}=n \times \mathrm{x}$ matrix, diagonals $(\mathrm{a} 11, \mathrm{a} 22$, g11 and g22) represent effect of own previous shocks and offdiagonals (a12, a21, g12, g21) show cross-market effects of shocks.

$\mathrm{H}_{\mathrm{t}}$ is further explained by following equations;

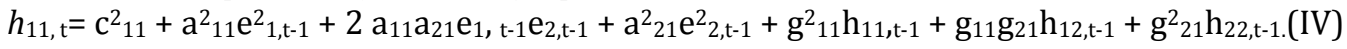

$h_{12, t}=c_{11} c_{21}+a_{11} a_{12} e^{2} 1, t-1+\left(a_{21} a_{12}+a_{11} a_{22}\right) e_{1, t-1} e_{2, t-1}+a_{21} a_{22} e^{2} 2, t-1+g_{11} g_{22} h_{11, t-1}+$

$\left(g_{21} g_{12}+g_{11} g_{22}\right) h_{12, t-1}+g_{21} g_{22} h_{22, t-1 .}$

$h_{22, t}=c^{2}{ }_{21} c^{2} 22+a^{2}{ }_{12} \mathrm{e}^{2} 1, t-1+2 a_{12} a_{22} \mathrm{e}_{1, t-1} \mathrm{e}_{2, \mathrm{t}-1}+\mathrm{a}^{2}{ }_{22} \mathrm{e}^{2} 2, \mathrm{t}-1+\mathrm{g}^{2}{ }_{12} \mathrm{~h}_{11, \mathrm{t}-1}+\mathrm{g}_{12} \mathrm{~g}_{22} \mathrm{~h}_{12, \mathrm{t}-1}+$

$\mathrm{g}^{2}{ }_{22} \mathrm{~h}_{22, \mathrm{t}-1 .}$.

In the same way, $\mathrm{a}_{21}$ and $\mathrm{g}_{21}$ are used to test causality effect form second market to first market.

Above-mentioned model can be assessed by the maximum likelihood estimation. There are two methods that can be used for maximum likelihood estimation, one is Marquardt maximum likelihood method and other one is BHHH algorithm. Mostly, studies have suggested that BHHH (Berndth, Hall, Hausman and Hall) algorithm is better estimator than Marquardt maximum likelihood method. From equation 2, we get following $\log$ likelihood function "L".

$\mathrm{L}=\sum_{t=1}^{T} L t$

Where,

$\mathrm{L}_{\mathrm{t}}=\frac{n}{2} \operatorname{Ln}(2 \pi)-\frac{1}{2} \operatorname{Ln}$ abs $\left(\mathrm{H}_{\mathrm{t}}\right)-\frac{1}{2} \mathrm{e}^{\prime}{ }^{\prime} \mathrm{H}_{\mathrm{t}}{ }^{-1} \mathrm{e}_{\mathrm{t}}$

\section{Results}

Descriptive Statistics: Table 1 presents extensive series of descriptive analyses to acquire expressive statistical generalizations, which are vital to obtain a well depiction of the actions of stock market weekly returns.The average weekly return of Karachi Stock Exchange of Pakistan, is 0.11 while India, Hong Kong and Singapore have $0.08,0.018$, and 0.048 respectively. Expected volatility is measured by standard deviation, which is also high in emerging economy like Pakistan against other developed economies. Distributional properties of weekly returns are seemed to be non-normal. All stock markets are negatively skewed and kurtosis that indicates degree of excess is more than 4in case of Pakistan and Singapore while close to 3 in 
case of India and Hong Kong, demonstrating a leptokurtic distribution. Finally, Jarque- Bera estimates normality of distribution. P-value of Jarque-Bara test is significant at the level of $1 \%$ in all cases, we accept alternative hypothesis and reject null hypothesis.

Table 1: Descriptive Statistics

\begin{tabular}{lllll}
\hline & PAK & IND & HK & SING \\
\hline Mean & 0.118672 & 0.087716 & 0.018979 & 0.048622 \\
SD & 1.66764 & 1.612277 & 1.443745 & 1.290491 \\
Kurtosis & 4.414025 & 2.918275 & 2.371217 & 4.903947 \\
Skewness & -1.16665 & -0.75545 & -0.26205 & -0.46724 \\
Min. & -8.7283 & -7.54838 & -7.73714 & -7.15212 \\
Max. & 5.556815 & 5.720052 & 5.089433 & 6.653627 \\
J.B. & 552.47 & 244.78 & 135.53 & 580.11 \\
Sig. & $0.000^{*}$ & $0.000^{*}$ & $0.000^{*}$ & $0.000^{*}$ \\
\hline
\end{tabular}

Figure 1: Weekly returns from 2000 to August 2011
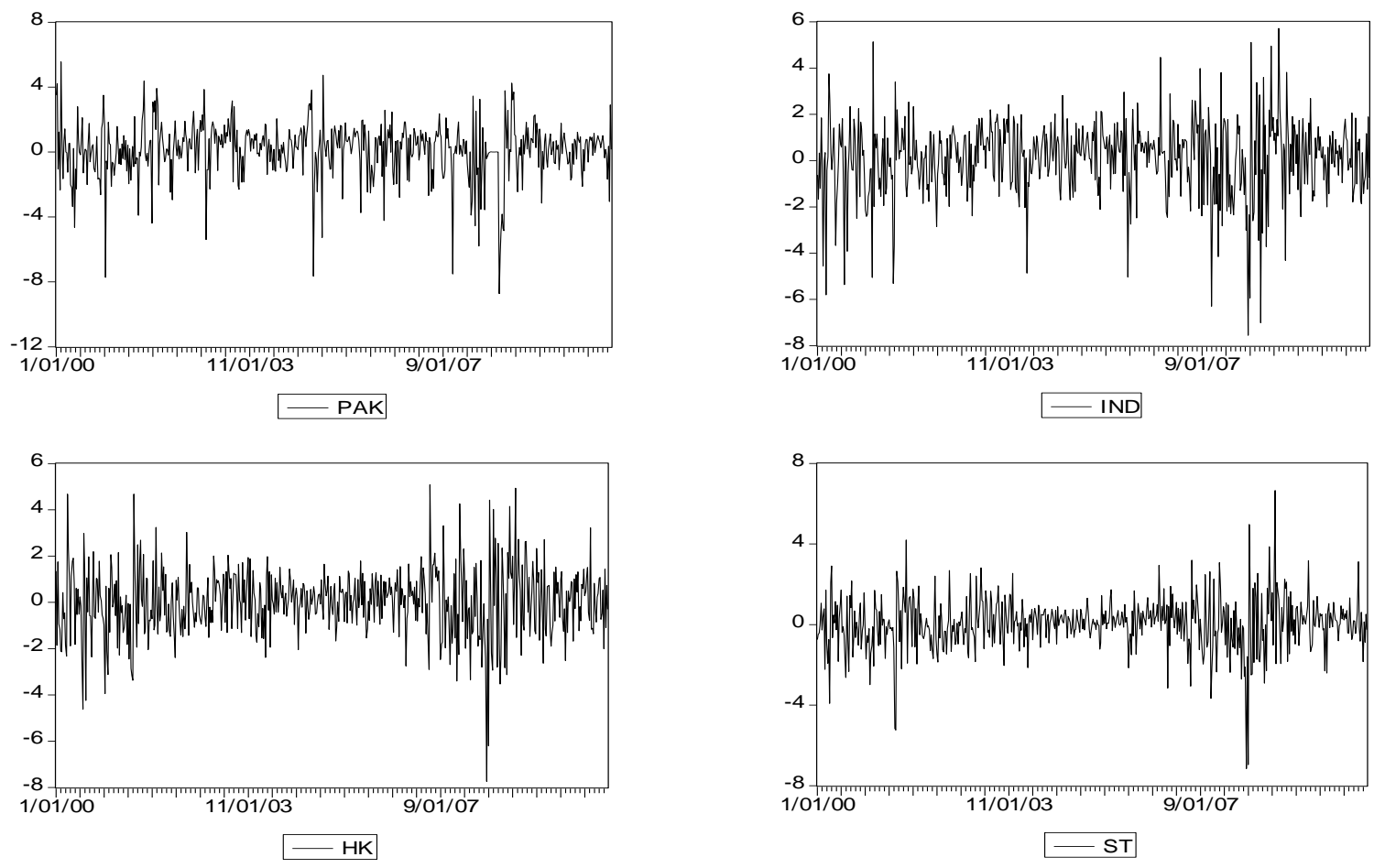

Empirical Outcomes of Volatility Linkages among Countries: Empirical outcomes response the theoretical questions expressed in earlier sections. To analyze the volatility linkages among equity markets of four countries, six pairs are assessed by employing Multivariate GARCH $(1,1)$ BEKK model. The pairs which are modeled for estimation, Pakistan-India, Pakistan-Singapore, Pakistan-Hong Kong, India-Singapore, IndiaHong Kong, Singapore-Hong Kong, using weekly returns from January 2000 to August 2011. First, we look at Table 2, which indicates volatility linkages among equity markets of four countries by using weekly returns. Mean equation (eq1) took by parameters $\mathbf{c}_{11}, \mathbf{c}_{\mathbf{2 1}}$ and $\mathbf{c}_{22}$, in which diagonal parameters $\mathbf{c}_{\mathbf{1 1}}$ is significant in case of Pakistan when they modeled with Hong Kong and India and Hong Kong when they modeled with Singapore suggesting that returns of Pakistan, India and Hong Kong are dependent on their first lag while $\mathbf{c}_{22}$ is significant in case of Pakistan when modeled with India and Hong Kong and insignificant in all other 
models. Insignificant models in case of mean equation show that their returns do not depend on their own previous returns. Mean spillover $\mathbf{c}_{21}$ is significant in all models instead of Pakistan when it modeled with India and Singapore. As far as volatility spillover is concerned, it is presented by matrices A and G, which capture ARCH and GARCH effect respectively. Diagonal elements of matrix A $\left(a_{11}, a_{22}\right)$ and matrix $G\left(g_{11}, g_{22}\right)$ capture the own ARCH and GARCH effects respectively. All diagonal parameters $\left(a_{11}, a_{22}, g_{11}, g_{22}\right)$ are significant, showing that there is strong ARCH and GARCH effect among all pairs of countries. Cross-market effect of shocks is captured by off-diagonal parameters of matrix $A\left(a_{12}, a_{21}\right)$ and $G\left(g_{12}\right.$ and $\left.g_{21}\right)$. Off-diagonal parameters $\mathrm{a}_{12}$ is significant in all models and $\mathrm{a}_{21}$ is significant in case of Pakistan when modeled with India and Hong Kong and in case of India when modeled with Hong Kong. Similarly, parameters $g_{12}$ and $g_{21}$ are bidirectional significant in case of Pakistan when it modeled with India and Singapore while unidirectional significant in case of Pakistan - Hong Kong, India - Singapore and Hong Kong Singapore. Results indicate that volatility spillover is higher in emerging economy like Pakistan than other developed economies like India, Hong Kong and Singapore. Lastly, autocorrelation in the standardized residuals are estimated by Ljung box Q test. Table 3 presents that $p$-value is insignificant in all series at $5 \%$ level of significance which show that there is no serial correlation among residuals.

Table 2: Multivariate GARCH $(1,1)$ BEKK Analysis by using weekly returns from 2000 to 2011

\begin{tabular}{|c|c|c|c|c|c|c|c|c|c|c|c|c|}
\hline \multirow{2}{*}{ Parameters } & \multicolumn{2}{|c|}{ PAK-IND } & \multicolumn{2}{|c|}{ PAK-HK } & \multicolumn{2}{|c|}{ PAK-SING } & \multicolumn{2}{|c|}{ IND-HK } & \multicolumn{2}{|c|}{ IND-SING } & \multicolumn{2}{|c|}{ HK-SING } \\
\hline & Coeff & t-stat & Coeff & t-stat & Coeff & t-stat & Coeff & t-stat & Coeff & t-stat & Coeff & t-stat \\
\hline $\mathrm{M}(1)$ & 0.163 & $2.890^{*}$ & 0.155 & $2.53^{*}$ & 0.160 & $2.85^{*}$ & 0.183 & $3.12^{*}$ & 0.087 & 1.519 & 0.075 & $1.84^{* *}$ \\
\hline $\mathrm{M}(2)$ & 0.111 & $1.873^{* *}$ & 0.079 & 1.504 & 0.082 & $1.83^{* *}$ & 0.121 & $2.31^{*}$ & 0.110 & $2.56^{*}$ & 0.088 & $2.22^{*}$ \\
\hline $\mathrm{c}_{(1,1)}$ & 0.007 & 0.025 & 0.325 & $1.89^{* *}$ & 0.014 & 0.110 & 0.388 & 1.177 & 0.168 & $3.57^{*}$ & 0.146 & $3.37^{*}$ \\
\hline $\mathrm{c}_{(2,1)}$ & -0.031 & -0.059 & 0.449 & $2.36^{*}$ & 0.412 & 0.773 & -0.727 & $-7.58^{*}$ & -0.175 & $-3.34^{*}$ & -0.196 & $-4.38^{*}$ \\
\hline $\mathrm{c}_{(2,2)}$ & 0.494 & $12.296^{*}$ & 0.300 & $1.75^{* *}$ & 0.153 & 0.111 & 0.004 & 0.000 & 0.000 & 0.000 & 0.000 & 0.000 \\
\hline $\mathrm{a}_{(1,1)}$ & 0.360 & $9.222^{*}$ & 0.347 & $3.79^{*}$ & 0.339 & $6.884^{*}$ & 0.041 & 0.491 & 0.201 & $6.38^{*}$ & 0.243 & $8.29 *$ \\
\hline $\mathrm{a}(1,2)$ & 0.210 & $5.405^{*}$ & 0.063 & $1.35^{*}$ & 0.062 & $1.707^{* *}$ & 0.153 & $1.82^{* *}$ & -0.177 & $-6.41^{*}$ & -0.181 & $-5.81^{*}$ \\
\hline $\mathrm{a}_{(2,1)}$ & -0.225 & $-6.450^{*}$ & 0.058 & $1.11^{*}$ & -0.073 & -1.166 & 0.320 & $4.01^{*}$ & 0.040 & 0.969 & 0.006 & 0.180 \\
\hline $\mathrm{a}_{(2,2)}$ & 0.180 & $4.460^{*}$ & 0.429 & $8.12^{*}$ & 0.386 & $5.298^{*}$ & 0.356 & $3.20^{*}$ & 0.377 & $7.97^{*}$ & 0.370 & $9.37^{*}$ \\
\hline $\mathrm{g}(1,1)$ & 0.740 & $50.861^{*}$ & 0.925 & $18.72^{*}$ & 0.926 & $50.10^{*}$ & 0.905 & $6.28^{*}$ & 0.975 & 113.83* & 0.961 & $88.94^{*}$ \\
\hline $\mathrm{g}_{(1,2)}$ & -0.438 & $-20.92^{*}$ & 0.032 & 0.71 & -0.098 & $-3.93^{*}$ & 0.282 & 1.346 & 0.064 & $6.73^{*}$ & 0.073 & $4.87^{*}$ \\
\hline $\mathrm{g}_{(2,1)}$ & 0.460 & 16.939* & -0.174 & $-4.74^{*}$ & 0.180 & $5.44^{*}$ & 0.027 & 0.133 & -0.022 & -1.463 & 0.001 & 0.039 \\
\hline $\mathrm{g}_{(2,2)}$ & 0.856 & $66.23^{*}$ & 0.812 & $21.25^{*}$ & 0.851 & $16.87^{*}$ & 0.494 & $2.12^{*}$ & 0.896 & $43.11^{*}$ & 0.898 & $43.73^{*}$ \\
\hline $\begin{array}{l}\text { Log } \\
\text { Likelihood }\end{array}$ & -2178.0 & & -2108.1 & & -2036.9 & & -1993.1 & & -1962. & & -1843.7 & \\
\hline
\end{tabular}

$C$ matrix represents mean equation, diagonals $\mathrm{a}_{11}$ and $\mathrm{a}_{22}$ of A matrix show the own while off-diagonals $\mathrm{a}_{12}$ and $\mathrm{a}_{21}$ capture cross-market ARCH effects. Similarly, diagonals $\mathrm{g}_{11}$ and $\mathrm{g}_{22}$ of G matrix demonstrate the own while off-diagonals g12 and g21 express cross-market GARCH effects.

*significant at the level of $5 \%{ }^{* *}$ significant at the level of $10 \%$

Table 3: Standardized Residual Test

\begin{tabular}{lllll}
\hline & PAK & IND & HK & SING \\
\hline LB Q stat & 17.355 & 8.850 & 4.712 & 10.555 \\
p-value & 0.184 & 0.115 & 0.452002 & 0.648 \\
\hline
\end{tabular}




\section{Conclusion}

Current study examines the volatility linkages among equity markets of Pakistan, India, Singapore and Hong Kong by using the multivariate GRCH BEKK model, which was proposed by Engle and Kroner (1995). We analyzed pair wise models (Pakistan-India, Pakistan-Singapore, Pakistan-Hong Kong, India-Singapore, IndiaHong Kong and Hong Kong-Singapore) using weekly returns from January 2000 to August 2011. We found associations among four markets with respect to the conditional mean returns and volatility. As far as volatility linkages are concerned, all markets are found to be significant in case of their own previous shocks that indicate that there is strong ARCH and GARCH effect among all countries. In case of cross-country effect, Pakistan is found to have strong bidirectional ARCH and GARCH effect regarding to weekly returns, which indicate the volatility linkages with developed equity markets. We can conclude that strong volatility linkages are found in case of own previous shocks as compare to cross country effect. This study can be further expanded in numerous ways. Further, we can examine the asymmetric effect. To investigate the negative effect of one equity market on other equity market, we can include dummies in this model.

\section{References}

Adwin, S. (2005). Are the five Asean stock price indices dynamically interacted? Journal akuntansi \& keuangan, 7(1), 43- 60.

Anoruo, E., Ramchander, S. \& Thiewes, H. (2003). Return Dynamics across the Asian Equity Markets. Managerial Finance, 29(4).

Beirne, J., Caporale, G., Schulze-Chattas, M. \& Spagnolo, N. (2009). Volatility spillovers and contagion from mature to Emerging stock markets. Working paper available at: http://d.repec.org/n?u=RePEc:diw:diwwpp:dp873\&r=fmk.

Bekaert, G. \& Harvey, C. R. (1997). Emerging equity market volatility. Journal of Finance and Economics, 43, 29-77.

Bollerslev, T. P. (1986). General Autoregressive Conditional Heteroskedasticity. Journal of Econometrics, 21, 307-327.

Choudhry, T. (2004). International transmission of stock returns and volatility: An empirical comparison between friends and foes. Emerging Markets Finance and Trade, 40(4), 33-52.

Dekker, A. K. \& Young, S. M. (2001). Equity market linkages in the Asia Pacific region. A comparison of the orthogonalised and generalized VAR approaches. Global Finance Journal, 12, 1-33.

Dimitrios, T. (2000). An Autoregressive Heteroskedastic in the Mean (ARCH-M) Analysis of International Stock Market Indexes. Managerial Finance, 26(12).

Engle, R. F. (1982). Autoregressive Conditional Heteroskedasticity with Estimates of the Variance of U.K. Inflation. Econometrica, 50, 987-1008.

Engle, R. F. \& Kroner, K. F. (1995). Multivariate simultaneous generalized ARCH. Econometric Theory, 11, 122150.

Hamao, Y., Masulis, W. \& Ng, V. (1990). Correlations in Price Changes and Volatility across International Stock Markets. Review of Financial Studies, 3(2), 281-307.

Hameed, A. \& Ashraf, H. (2006). Stock Market Volatility and Weak-form Efficiency: Evidence from an Emerging Market. Pakistan Development Review, 45(4), 1029-1040.

Hashmi, R. \& Liu, X. (2001). Inter-linkages among south East Asian stock markets (A Comparison Between Pre- and Post-1997-Crisis Periods).Conference paper.

Hyytinen, A. (1999). Stock Return Volatility on Scandinavian Stock Markets and the Banking Industry. Bank of Finland discussion papers 19/99.

Isakov, D. \& Pérignon, D. (2000). On the dynamic interdependence of international stock markets: A Swiss perspective. Swiss Journal of Economics and Statistics, 136(2), 123-146.

Kenen, P. (1976). Portfolio adjustment in open economies: A comparison of alternative specifications. Review of World Economics, 112(1), 33-72.

King, M. \& Wadhwani, S. (1989).Transmission of volatility among Stock Markets. NBER working paper: 2910.

Kumar, B., Pandey, A. \& Priyanka, S. (2008). Price and Volatility Spillovers across North American, European and Asian Stock Markets: With Special Focus on Indian Stock Market. Available at: http://ssrn.com/abstract $=1324350$ 
Ramchand, L. \& Susmel, R. (1998). Volatility and cross correlation across major stock markets. Journal of Empirical Finance, 5(4), 397-416.

Roca, E. D. (1999). Short-term and long-term price linkages between the equity markets of Australia and its major trading partners. Applied Financial Economics, 9, 501-511.

Sabri, N. (2006). Globalization and Stock Market Stability. Available at: http://ssrn.com/abstract=899708.

Saleem, K. (2009). International linkage of Russian market and Russian financial crisis: a multivariate Garch analysis. Research in International Business and Finance, 23, 243-256.

Sariannidis, N., Konteos, G. \& Drimbetas, E. (2006). Volatility linkages among India, Hong Kong and Singapore stock markets. Available at: http://ssrn.com/abstract=1340591.

Syllignakis, N. \& Kouretas, P. (2008). Switching volatility in emerging stock markets: Evidence from the new EU member countries. Available at SSRN: http://ssrn.com/abstract=1099510.

Tay, N. S. P. \& Zhu, Z. (2000). Correlations in returns and volatilities in Pacific-Rim stock markets. Open Economics Review, 11, 27-47.

Worthington, A. \& Higgs, H. (2004). Transmission of equity returns and volatility in Asian developed and emerging markets: A multivariate GARCH analysis. International Journal of Finance and Economics, 9, 71-80.

Worthington, A. C., Katsuura, M. \& Higgs, H. (2001). Price Linkages in Asian Equity Markets and the Asian Economic, Currency and Financial Crises. School of Economics and Finance, Queensland University of Technology, Brisbane, Queensland, Discussion Paper, 77. 